\title{
Design and Development of Web Service Application for Multi-Bank Student Payment System in State University of Jakarta
}

\author{
Muhammad F. Duskarnaen ${ }^{1}$, Muhammad Insan Rizky², and \\ Achmad Ahlar Ridha ${ }^{3}$ \\ ${ }^{1}$ Information and Communication Technology, State University of Jakarta, Jakarta 13220, \\ Indonesia \\ ${ }^{2}$ Graduate Student, IT Developer in Information and Communication Technology, State \\ University of Jakarta, Jakarta 13220, Indonesia \\ ${ }^{3}$ Under Graduate Student, IT Developer in Information and Communication Technology, State \\ University of Jakarta, Jakarta 13220, Indonesia
}

\section{Abstract}

Payment System for student tuition fee in Jakarta State University is a web-based software that is functioned to support student payment activities both for prospective

Corresponding Author: Muhammad F. Duskarnaen duskarnaen@unj.ac.id

Received: 11 January 2019 Accepted: 14 February 2019 Published: 25 March 2019

Publishing services provided by Knowledge E

(c) Muhammad F. Duskarnaen et al. This article is distributed under the terms of the Creative Commons Attribution License, which permits unrestricted use and redistribution provided that the original author and source are credited.

Selection and Peer-review under the responsibility of the 3rd ICTVET 2018 Conference Committee. student payments and for registered student payments. Provision for this process includes updating the payment status that is integrated with the bank, as well as payment history from time to time. During this time to serve the payment process of 24,000 students, UNJ established a partnership to pay student tuition fees with four banks, namely BNI, Mandiri, Bukopin, and the latest with BTN. The four banks have different student payment segments, namely for Diploma, Under Graduate, and Post Graduate programs [1]. In this bank payment, we must create a special application known as the Host-to-Host application that connects banks with university databases, each of every bank. The problems appear when the data and formats used in each bank are different, this makes enormous problems when the final record process. This web service application shall enable the multibank student payment management process that has the same data standards and formats that are integrated with banks, neat recording, and integration with academic information systems and UKT systems.

Keywords: web service, single tuition fee (Uang Kuliah Tunggal/UKT), Host to Host

\section{Introduction}

The absence of a multi-bank payment system at UNJ, including its standards and application has caused so many problems not only the students but also university administration. These different systems cause the students' data to be out of sync in the finance and academic departments. 
Payment System Jakarta State University is a web-based software that is functioned to support student payment activities both for prospective student payments and for registered student payments. Support for this process includes updating the payment status that is integrated with the bank, as well as payment history from time to time.

With the above conditions it is necessary to create an web service application for multi bank student payment system in State University of Jakarta.

\section{Methods Methodology}

\subsection{Research focus}

The purpose of this research is to design and building web service application system in the form of UNJ Integrated Payment System Application in Host To Host with Multi Bank. The outcome of this research are Software Requirement Specification (SRS) and web application.

\subsection{Research methodology}

The first process in this study is to formulate the problems described in the previous discussion. After that, conduct a needs analysis based on the SRS that has been made by the UPT ICT team to see the existing data needs.

After a needs analysis, the next is to do a database design and web service according to the needs of the system created. A web service is a network accessible interface to application functionality, built using standard Internet technologies [2]. This is illustrated in Figure 1. After designing, we are building a database and web service in accordance with the results of the design and testing using Postman method for both. If we still have errors, then we have to look at the design and the results of the coding script to trace the error. After all is finished and the web service is declared successful and feasible, then drawing conclusions and suggestions is made.

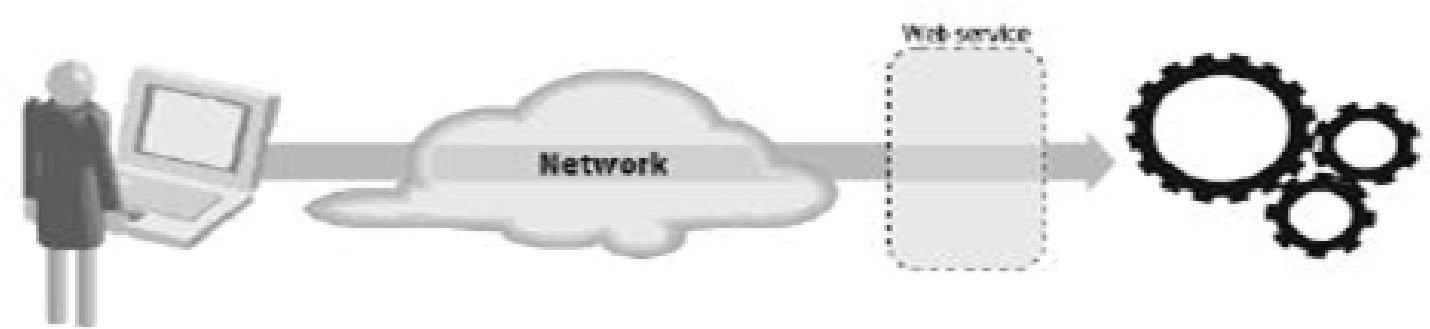

Figure 1: Web Service [2]. 
As for completing the completeness of the data, the author uses the Observation (observation) technique for data collection, at this stage an observation activity is carried out on the software requirement specification that has been made by the Information Technology and Information Technology Technical Implementation Unit of the State University of Jakarta to see the available data needs.

The test uses the unit testing method which is the testing carried out on each endpoint produced during the web service development process. This test is conducted to find out whether the web service is functioning properly in accordance with the requirements that have been determined.

We described the Use Case for the Payment system in Figure 2 and Student Tuition Fee Payment Process in Figure 3.

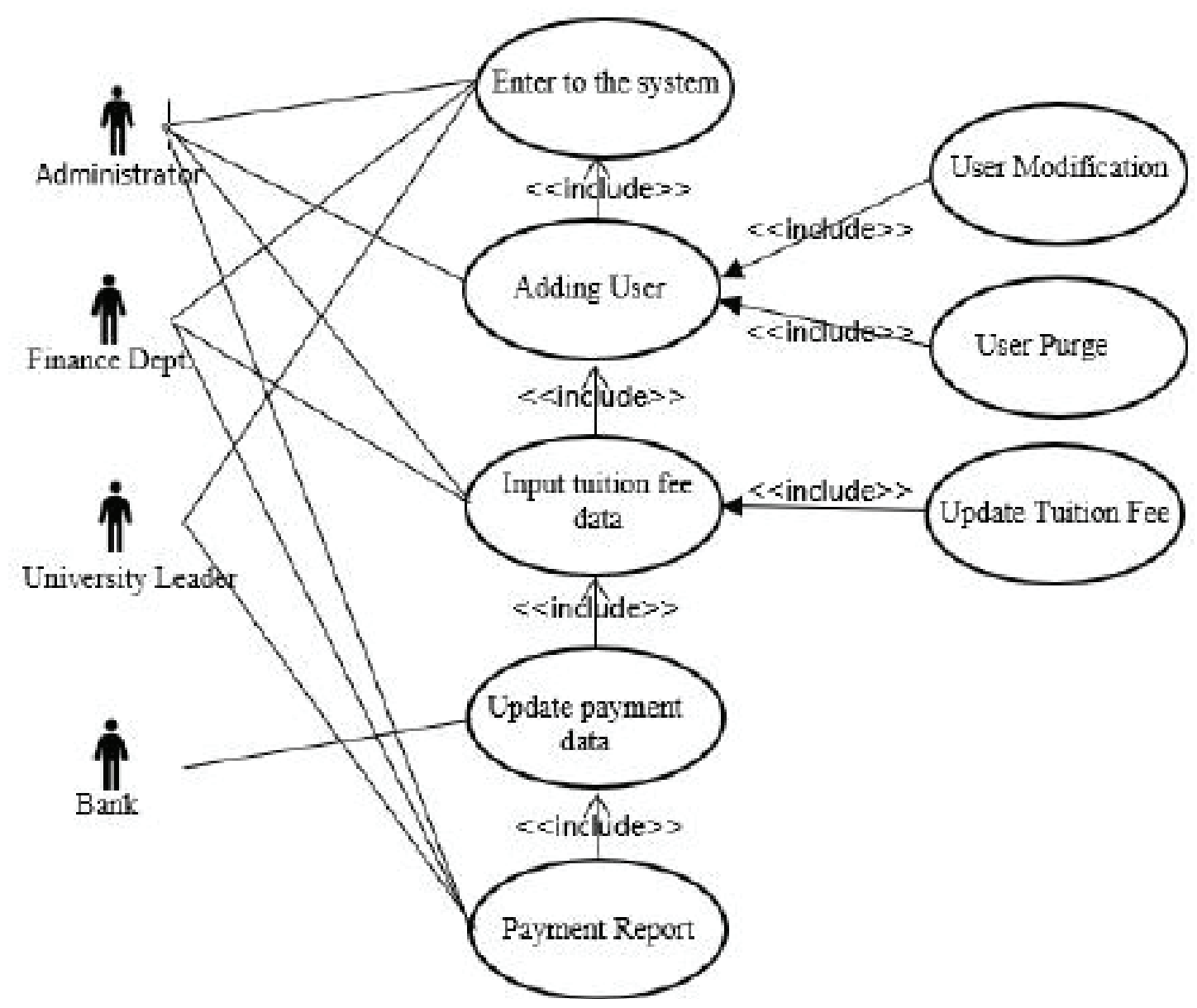

Figure 2: Payment System Use Case. 


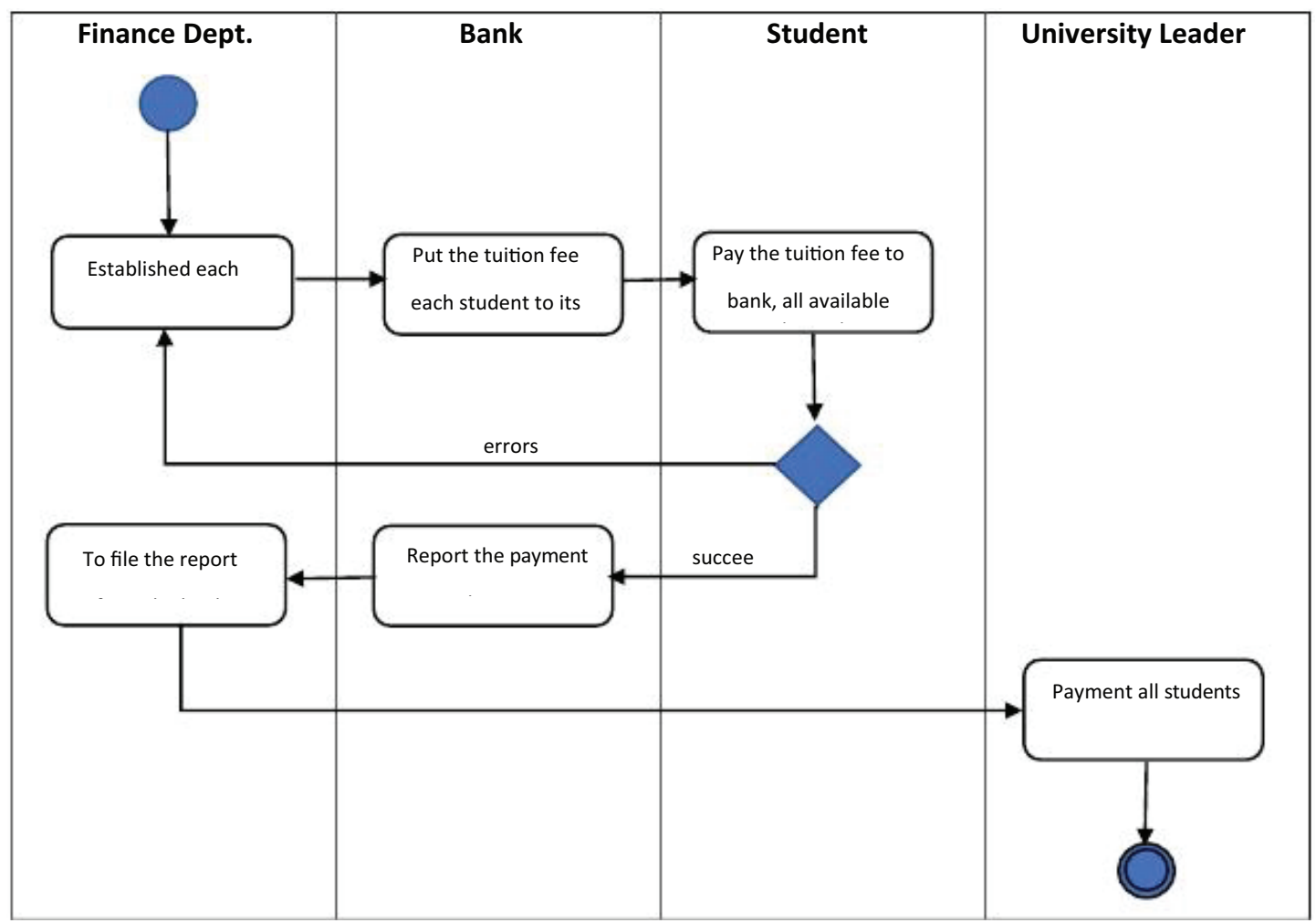

Figure 3: Student Tuition Fee Payment Process.

\subsection{Specification}

In web service, the requirement table is shown in Table 1.

TABLE 1: Web Service requirement.

\begin{tabular}{ll} 
Column Name & Data Type \\
id & Number (INT) \\
\hline No_reg & Student's Register Number (STRING) \\
Nominal & Nominal Payment in IDR (FLOAT) \\
\hline Jenis_pembayaran & Type of payment (ENUM) \\
Start_date & Opening date for payment \\
End_date & Last date for payment \\
\hline Keterangan & Notes \\
Status & Payment status, paid, failure, not yet paid
\end{tabular}

\subsection{Requirement analysis}

The requirement analysis is shown in Table 2 . 
TABLE 2: Requirement Analysis.

\begin{tabular}{|c|c|}
\hline Requirement & Reasons \\
\hline Payment status & What is needed by the bank and pustikom \\
\hline Payment log table & To record all payment transactions \\
\hline Failure Status & For handling errors if there is a failure in the system \\
\hline $\begin{array}{l}\text { University Financial Information } \\
\text { System }\end{array}$ & $\begin{array}{l}\text { There needs to be a Financial Governance Information System } \\
\text { at UNJ }\end{array}$ \\
\hline Web Service & Web Service as the recipient of WSDL documents \\
\hline User Interface & $\begin{array}{l}\text { As the screen for the Reporting Engine interface and the need } \\
\text { for recapitulation }\end{array}$ \\
\hline
\end{tabular}

\section{Result}

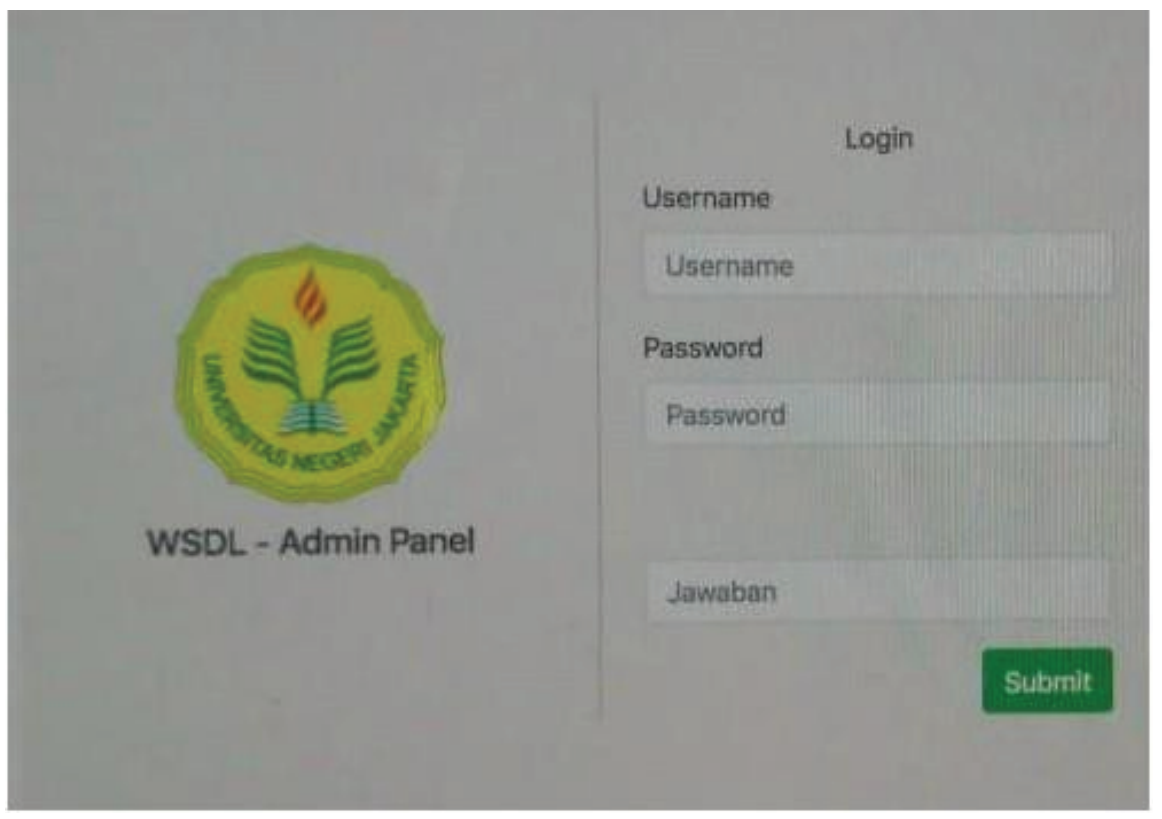

Figure 4: Ul template for Administrator.

The illustration of the user interface display can be seen in Figure 4. In Figure 4 shown the login user interface for the administrator. Basically all other stakeholders, university leaders, banks, finance departments have a similar appearance, except for students of course as they only need to pay at the bank.

With a standard username and password, logging in to the application is added with additional security questions to avoid breaking into unwanted applications.

\section{References}

[1] Buku Pedoman Akademik FT tahun 2016, UNJ. 
[2] Doug Tidwell, James Snell, Pavel Kulchenko (2001). Programming Web Services with Soap. Oreilly.

[3] Erien Nada Azandra(2017). Host To Host Payment System Pada Politeknik Ati Padang. Jurnal Sains dan Informatika E-ISSN:2502-096X.

[4] Meta Lara Pandini, Zainal Arifn and Dyna Marisa Khairina (2014). Design Web Service Academic Information System Based Multiplatform. 2014 Ist International Conference on Information Technology, Computer and Electrical Engineering (ICITACEE).

[5] Arif Firmansyah(2017). Implementasi Services Oriented Architecture (SOA) Dalam Sistem Transaksi Perbankan di Perguruan Tinggi Studi Kasus: Universitas Padjadjaran. ISSN: 2088-8252 page 169-174. 